\title{
KONTRIBUSI TATA TERTIB SEKOLAH TERHADAP PRESTASI BELAJAR PKN SISWA PADA SMP NEGERI 1 BAJENG KABUPATEN GOWA
}

\author{
Oleh: \\ IMAM SUYITNO \\ MULYADI RASYID \\ Dosen Jurusan PPKn FIS Universitas Negeri Makassar
}

\begin{abstract}
ABSTRAK: Penelitian ini bertujuan untuk mengetahui: (1) Kontribusi antara tata tertib sekolah dengan prestasi belajar PKn siswa pada SMP Negeri 1 Bajeng Kabupaten Gowa, (2) Kendala-kendala yang dihadapi pihak sekolah dalam penegakan tata tertib, (3) Upaya-upaya yang dilakukan pihak sekolah dalam penegakan tata tertib sekolah di SMP Negeri 1 Bajeng Kabupaten Gowa. Penelitian ini merupakan penelitian deskriptif kuantitatif dengan populasi seluruh peserta didik kelas VIII SMP Negeri 1 Bajeng, yang berjumlah 150 peserta didik sehingga dilakukan penerikan sampel dengan menggunakan teknik purposive sampling, dan mengambil paralel setiap kelasnya sehingga jumlah sampel sebanyak 30 peserta didik dan 2 guru sebagai Informan penelitian yang terdiri dari guru BK dan guru PKn. Teknik pengumpulan data yang digunakan adalah angket, wawancara, dan dokumentasi, analisis data yang digunakan adalah uji korelasi Product Moment. Dari analisis uji hipotesis melalui rumus korelasi Product Moment dari Pearson bahwa ada kontribusi tata tertib sekolah terhadap prestasi belajar PKn siswa pada SMP Negeri 1 Bajeng Kabupaten Gowa, hal ini ditunjukkan dari nilai koefisien korelasi sebesar 0,998 kemudian dikonsultasikan denga nilai pada taraf signifikan $\alpha=5 \%$ dengan ketentuan jika nilai hitung $>$ nilai tabel pada taraf signifikan $\alpha=5 \%$ maka hipotesis diterima , sebaliknya jika nilai hitung $<$ dari nilai tabel pada taraf signifikan $\alpha=5 \%$ maka hipotesis ditolak. Adapun hasil perhitungan tabel pada taraf signifikan $\alpha=5 \%$ menghasilkan nilai hitung $=0,998$, sedangkan nilai tabel $=0,361$ karena nilai hitung $>$ nilai tabel maka hipotesis yang diajukan diterima. Artinya ada kontribusi tata tertib sekolah dengan prestasi belajar PKn siswa pada SMP Negeri 1 Bajeng, adapun kendala-kendala yang dihadapi pihak sekolah dalam penegakan tata tertib antara lain:(1) kerja sama antara guru BK dengan guru mata pelajaran dan wali kelas belum maksimal,(2) orang tua siswa belum terlalu peduli pada anaknya. Selain itu juga adapun upaya-upaya yang ditempuh pihak sekolah dalam penegakan tata tertib antara lain:(1) memberikan pengarahan,(2) menjalin kerja sama dengan orang tua siswa,(3) pemberian contoh keteladanan.
\end{abstract}

\section{Kata Kunci: Tata tertib Sekolah, Prestasi Belajar}

ABSTRACT: This study aims to determine: (1) The contribution of school discipline and academic achievement Civics students at SMP Negeri 1 Bajeng Gowa, (2) constraints faced by the school in enforcing the regulations, (3) Efforts carried out by the school in enforcing the school rules in SMP Negeri 1 Bajeng Gowa. This research is quantitative descriptive with population of all students in grade VIII SMP Negeri 1 Bajeng, totaling 150 students that do penerikan sample using purposive sampling techniques, and take parallel each class so that the total sample of 30 students and 2 teachers as informants the research consisted of teachers and teacher BK Civics. Data collection techniques used were questionnaires, interviews, and documentation, analysis of the data used is the product moment correlation test. From the analysis of hypothesis testing through correlation formula of Pearson Product Moment that no contribution the school rules on learning achievement Civics students at SMP Negeri 1 Bajeng Gowa, it is shown on the 
value of the correlation coefficient of 0.998 were consulted premises value at significance level $\alpha=5 \%$ with the provision that if the calculated value $>$ value table at significance level $\alpha=5 \%$, then the hypothesis is accepted, whereas if the calculated value <value table at significance level $\alpha=5 \%$, then the hypothesis is rejected. The results of the calculation table at significance level $\alpha=5 \%$ yield calculated value $=0.998$, while the value table for the calculated value $=0.361>$ table value then the hypothesis is accepted. This means that any contribution school discipline and academic achievement Civics students at SMP Negeri 1 Bajeng, while the constraints faced by the school in the enforcement of the order include: (1) cooperation between BK teachers with subject teachers and homeroom is not maximized, (2) the parents have not been too concerned about his son. In addition, as for the efforts taken by the school in the enforcement of the order include: (1) provide guidance, (2) establish cooperation with parents, (3) the provision of exemplary examples.

Keywords: Rules Schools, Achievement

\section{PENDAHULUAN}

Kegiatan penyelenggaraan pendidikan merupakan suatu usaha yang dimaksudkan untuk membantu siswa mencapai kedewasaan, yang harus diselenggarakan dalam suatu kesatuan cara berbuat yang diorganisir,sehingga antara usaha yang satu dengan usaha yang lain saling berhubungan dan saling menunjang. Akan tetapi dunia pendidikan dewasa ini menghadapi berbagai masalah yang amat kompleks yang perlu mendapatkan perhatian khusus bagi kita semua salah satu masalah tersebut adalah menurunya kesadaran siswa dalam mentaati tata terib sekolah sehingga mengakibatkan sejumlah perilaku negative. Siswa dalam kegiatan belajar mengajar dapat dianggap sebagai seorang individu dalam suatu masyarakat kecil yaitu sekolah. Mereka diharapkan mengetahui hak-haknya sebagai bagian dari kesatuan dalam kelas disamping mereka juga harus tahu kewajibannya dan keharusan menghormati hak-hak siswa yang lain.

Bahwa apapun tindakan yang dilakukan guru yang tujuannya untuk menciptakan dan mempertahankan kondisi yang optimal bagi terjadinya kegiatan belajar mengajar termasuk kegiatan penggelolaan kelas. Siswa harus sadar bahwa kalau mereka menggangu temannya yang sedang belajar tidak melaksanakan kewajiban sebagai anggota, kelompok pokok dalam pendidikan bahwa tertib belajar berkolerasi positif terhadap tinggi rendahnya prestasi belajar siswa disekolah.

Jadi penerapan sikap tertib dalam kegiatan belajar mengajar adalah suatu perbuatan dan kegiatan belajar yang dilaksanakan sesuai dengan aturan yang telah ditentukan sebelumnya.ketertiban belajar sebagai suatu keharusan yang harus ditaati oleh setiap person dalam suatu unit kerja atau setiap sekolah,dengan sendirinya memiliki aktivitas yang bernilai tambah. unsur pokok dalam tata tertib siswa adalah tertib kearah siasat yang baik.

Tujuan pendidikan dapat tercapai secara optimal diperlukan suasana yang mendukung kegiatan belajar mengajar maupun pembinaan pribadi. Dalam kehidupan bersama, hal ini dapat terbentuk dengan adanya aturan hidup bersama yang disebut tata tertib.Selama ini banyak para siswa yang mempunyai anggapan bahwa tata tertib sekolah hanya membatasi kebebasan mereka sehingga berakibat pelanggaran terhadap peraturan itu sendiri. Akan tetapi tanpa disadari akibat dari kebebasan yang kurang dipertanggungjawabkan itu akan merugikan dirinya sendiri, keluarga dan juga masyarakat. 
Dengan adanya pelaksanaan tata tertib ini tentunya mempunyai tujuan agar siswa mengetahui tugas, hak dan kewajibannya. Agar siswa mengetahui hal-hal yang diperbolehkan dan kretifitas meningkat serta terhindar dari masalahmasalah yang dapat menyulitkan dirinya. Agar siswa mengetahui dan melaksanakan dengan baik dan sungguh-sungguh seluruh kegiatan yang telah diprogramkan oleh sekolah. Menempelkan peraturan tata tertib pada dinding yang mudah dibaca oleh peserta didik beserta dengan sanksi bagi yang melanggar, sehingga peserta didik selalu ingat terhadap sanksi apabila melanggar aturan tersebut merupakan Salah satu wujud untuk meningkatkan kepatuhan peserta didik terhadap peraturan tata tertib sekolah. Tata tertib sekolah pada hakikatnya bukan hanya kelengkapan adminstrasi sekolah saja, tetapi haruslah menjadi bagian dari kehidupan peserta didik serta merupakan kebutuhan dari pada sekolah itu sendiri. Karena dengan adanya kepatuhan peserta didik terhadap tata tertib tersebut maka akan menciptakan kedisiplinan sekolah tersebut, maka mampu menciptakan suasana aman dan tertib demi lancarnya proses pendidikan di sekolah.

\section{TINJAUAN PUSTAKA}

1. Pengertian kedisiplinan terhadap tata tertib dalam belajar

Untuk mengetahui secara mendasar tentang pengertian kedisiplinan adalah melaksanakan sesuatu sesuai dengan aturan.Kepatuhan adalah sikap patuh,ketaatan (Hasan Alwi.838) Sedangkan taata tertif secara etimologis kedua ungkapan itu berarti kepatuhan. "Tertib ialah latihan hati dan watak dengan maksud supaya segala perbuatannya selalu mentaati tata tertib

Upaya menciptakan kedisiplinan peserta didik terhadap tata tertib yang ada di sekolah adalah untuk mengurangi penyimpangan yang berdampak pada prilaku peserta didik yang juga sebagai alat control atau rekayasa sosial terhadap peserta didik. Sebagaimana diketahui dewasa ini banyak sekali siswa sekolah yang terlibat dalam kenakalan remaja, pergaulan bebas, penggunaan narkoba, tawuran antar sekolah serta penggunaan etika yang salah dalam kehidupan. Oleh karena itu melalui pembinaan tata tertib sekolah diharapkan siswa dibiasakan melaksanakan kehidupan sesuai dengan aturan yang berlaku di masyarakatnya

$$
\text { Pengalaman dasar dalam }
$$

ketertiban akan memberikan dasar dalam keteraturan hidup selanjutnya. Tertib diri sendiri hanya akan tumbuh dalam suatu suasana dimana diantara guru dan para siswa terjalin sifat persahabatan yang berakar pada dasar saling menghormati dan saling percaya mempercayai.Hal ini tumbuh dan berkembang dari diri siswa apabila guru:

1. Bersikap hanya dalam membina sikap persahabatan dengan semua siswa menghargai mereka dan menerima mereka dengan berbagai keterbatasannya.

2. Bersikap adil sehingga siswa merasa diperlakukan sama tanpa tumbuh rasa dianak tirikan atau disisihkan.

3. Bersikap objektif terhadap kesalahan siswa dengan melakukan sanksi sesuai dengan kontrak sosial bila siswa melanggar tertib yang telah disetujui bersama.

4. Tidak menuntut para siswa untuk mengikuti aturan-aturan yang diluar kemampuan siswa untuk mengikutinya.

5. Dapat menciptakan suatu kondisi sehingga setiap siswa merasakan berhasil dalam segi-segi tertentu dan tidak senantiasa berada dalam situasi kegagalan dan kekecewaan.

6. Suasana disekolah tidak mendorong siswa kearah timbulnya tingkah laku yang tidak dikehendaki.

7. Pada saat tertentu disediakan hadiah dan penghargaan bagi siswa yang bertingka laku sesuai tuntutan tertib 
yang baik dan berlaku sebagai suri tuladan.

Sikap guru yang demokratis merupakan kondisi bagi terbinanya tertib kearah siasat,sikap ini akan memberi kesempatan kepada siswa untuk ikut terlibat dalam mengadakan tertib sekolah ,ikut bertanggung jawab dan ikut mempertahankan aturan yang dipikirkan dan ditetapkan bersama.Tentu saja hal ini dibutuhkan kerja sama yang baik dengan orang tua dirumah agar kebiasaan yang baik disekolah ditunjang oleh kebiasaan baik dirumah.demikian pula sebaliknya

1. Penanggulangan Pelnggaran Tata Tertib Sekolah

Teknik dan cara penanggulangan pelanggaran tata tertib yaitu:

a. Pengenalan Siswa

Makin baik guru mengenal siswa makin besar kemungkinan guru untuk mencegah terjadinya pelanggaran tertib .Sebaliknya anak yang frustasi karena merasa tidak mendapat perhatian guru dengan semestinya sangat mungkin terjadi siswa melanggar pada dasarnya mempunyai daya atau tenaga untuk mengawasi dirinya.

Siswa yang tidak diperhatikan orang tua dan guruhnya dan kurang dapat mengawasi dirinya sendiri biasanya kurang menghargai otoritas bahwa mereka tidak menyukai dan membencinya.Pengenalan terhadap mereka dan latar belakangnya merupakan usaha penanggulangan pelanggaran tertib.

b. Pengeksperesikan Perasaan

Memberikan penyuluhan yang sehat terhadap berbagai perasaan yang terteka yang dapat merupakan sumber pelanggaran tertib dalah usaha yang secara sadar harus dilakukan guru.

Jadi suatu kecemasan dikatakan berada pada tingkat cukup apabila kecemasan itu telah dapat menimbulkan kesadaran untuk mentertibkan diri guna melakukan sesuatu positif,dikatakan positif karena ada kemungkunan kekuatan-kekuatan superego itu sedemikian kuatnya sehingga
2. Pengertian Belajar dan Prestasi Belajar

Belajar dan Prestasi belajar adalah dua kata yang pengertiannya berhubungan antara satu dengan yang lain.Sehingga kadang kala sulit dipisahkan bahkan dibedakan pengertiannya antara satu dengan yang lainnya .

a. Pengertian belajar

Cukup banyak pendapat para ahli yang mengemukakan pengertian mengenai belajar, namun dalam pembahasan ini .penulis hanya mengemukakan beberapa saja diantarannya, P.M, Lwalata (1990:17) Mengemukakan bahwa: "Belajar adalah suatu perubahan pada kepribadian yang nyata dengan adanya pola sambutan yang baru dapat berupa suatu kecakapan ,suatu sikap suatu kebiasaan ,suatu abiliteit atau suatu pengertian"

Sedangkan pendapat T.Raka Joni mengemukakan pendapatnya yang dikutip oleh Frans Bona (1996:21) bahwa: "Belajar adalah pengaruh tingka laku sebagai hasil pengalaman ,kecuali perubahan itu disebabkan oleh proses untuk menjadi matangnya seseorang oleh perubahan yang insting atau temporer.

Dari beberapa ahli yang telah diuraikan diatas, dapat disimpulkan bahwa belajar adalah suatu proses perubahan tingkah laku yang meliputi pengetahuan,sikap dan keterampilan sebagai hasil pengalaman individu itu sendiri ,dimana perubahan itu bersifat permanen.tidak termasuk dalam pengertian belajar apabila perubahan tingkah laku individu itu disebkan oleh proses untuk menjadi matangnya seseorang oleh perubahan yang bersifat temporer.

Apabila dianalisis lebih lanjut dari pendapat para ahli yang telah dikemukakan tersebut, maka terdapat unsur terkandung dalam pengertian belajar antara lain :

1) Belajar itu merupakan suatu proses perubahan tingka laku dari orang yang belajar. 
2) Belajar itu mengandung factor kesengajaan dan kesadaran serta mempunyai tujuan.Belajar adalah merupakan suatu perubahan perilaku yang relative menetap (bersifat tidak sementara)

3) Perubahan tingka laku yang terjadi dalam belajar meliputi pengetahuan,sikap,dan

keterampilan.

4) Perubahan tingka laku seseorang merupakan hasil pertautan antara stimulus dan respon dalam bentuk pengalaman ,baik disengaja maupun tidak disengaja dalam proses belajar .

Belajar sebagai suatu kegiatan yang disadari berarti bahwa belajar yang dilakukan sudah dipertimbangkan sebelumnya,bukan dilakukan secara tibatiba atau secara refleks.Kegiatan belajar itu diarahkan pada suatu tujuan yang ingin dicapai yakni perubahan tingka laku positif yang pada dasarnya mencakup tiga aspek yakni pengetahuan,sikap dan keterampilan dimana perubahan tingka laku ini disebabkan sebagai hasil pengalaman yang diperoleh dalam interaksi dengan lingkungan.

b. Pengertian prestasi belajar

Secara umum prestasi diartikan sebagai suatu hasil yang dicapai dalam suatu usaha.jika usaha ini dimaksudkan adalah belajar ,maka prestasi dapat diartikan sebagai hasil yang dicapai setelah melalui proses belajar selama waktu tertentu.

Dari uraian di atas,kalau dirangkum dan ditinjau secara umum,tujuan belajar itu ada tiga jenis:

1. Untuk mendapatkan pengetahuan

Hal ini ditandai dengan kemampuan berfikir .pemilihan pengetahuan dan kemampuan berpikir sebagai yang tidak dapat dipisahkan.Dengan kata lain tidak dapat mengembangkan kemampuan berfikir tanpa bahan pengetahuan sebaliknya kemampuan berpikir akan memperkaya pengetahuan.Tujuan inilah yang memiliki kecenderungan lebih besar perkembangannya didalam kegiatan belajar. Dalam hal ini peranan guru sebagai pngajar lebih menonjol.

Adapun jenis interaksi atau cara yang dipergunakan untuk kepentingan itu pada umumnya dengan model kuliah (presentase),pemberian tugas-tugas bacaan. Dengan cara demikian anak didik akan diberikan pengetahuannya dan sekaligus akan menerimanya sendiri untuk mengembangkan cara berpikir dalam rangka memperkaya pengetahuannya.

2. Peranan Konsep dan keterampilan Peranan konsep atau merumuskan konsep ,juga memerlukan suatu keterampilan ,jadi soal keterampilan yang bersifat jasmani atau rohani.Keterampilan jasmaniah adalah keterampilanketerampilan yang dapat dilihat,diamati, sehingga akan menitikberatkan pada keterampilan gerak/penampilan adri anggota tubuh seseorang yang sedang belajar.Termasuk dalam hal ini masalahmasalah teknik dan pengulangan .Sedangkan keterampilan rohani lebih rumit ,karena lebih abstrak ,menyangkut persoalan -persoalan penghayatan dan keterampilan berfikir serta kreativitas untuk menyelesaikan dan merumuskan suatu masalah atau konsep.Jadi sematamata soal-soal pengulangan ,tetapi mencari jiwa yang cepat dan tepat.

Keterampilan itu memang dapat dididik,yaitu dengan banyak melatih kemampuan.demikian juga mengungkapkan perasaan melalui bahasa tulisan, bukan soal kosa kata atau tata bahasa ,semua memerlukan banyak latihan ,Interaksi yang mengarah pada pencapaian keterampilan itu atau menurut kaidah-kaidah tertentu dan bukan sematamata hanya menghafal atau meniru.Cara berinteraksi,misalnya dengan role playing.

3. Pembentuakan sikap

Dalam membutuhkan sikap mental,perilaku dan pribadi anak didik ,guru harus lebih bijak dan hati-hati dalam peendekatannya.untuk itu dibutuhkan 
kecakapan mengarahkan motivasi dan berfikir dengan tidak lupa menggunakan pribadi guru itu sendiri contoh aatau model.Situasi yang seperti telah dibahas terdahulu.Akan tetapi tujuan yang sebenarnya adalah siswa mempelajari dulu hal-hal yang meemang berguna sehingga patut untuk dipelajari, Mengingat proses belajar,jelas belajar ini mempunyai ciri-ciri tersendiri .Dan proses belajar mendapatkan pengetahuan tentang fakta-fakta yang unik dan kebetulan,karena sebenarnya ada kemungkinan bahwa fakta-fakta yang terjadi itu dapat menampakkan diri dalam bentuk lain.Bentuk belajar yang berikut adaah menghafal.Sepintas seakan-akan bentuk proses belajar ini sama saja dengan apa yang baru saja kita bahas diatas. Tetapi antara menghafal dan belajar mendapatkan fakta-fakta terdapat perbedaan-perbedaan yang cukup besar.Menghafal bertujuan untuk memproduksiannya kembali persis seperti yang telah dicamkannya.

\section{METODE PENELITIAN}

A. Pendekatan dan jenis penelitian Dalam penelitian ini perlu dimasukkan dengan tegas metode yang digunakan yaitu metode penelitian kuantitatif, alasan mengapa peneliti memilih metode tersebut karna memuat bagian-bagian dan hubunganhubungannya,

\section{B. Variabel dan Desain Penelitian}

\section{Variabel Penelitian}

Penelitian ini adalah penelitian korelasi yang dimaksudkan untuk mengetahui ada tidaknya kontribusi tata tertib sekolah dalam meningkatkan prestasi belajar PKn siswa pada SMP Negeri 1 Bajeng.

Berdasarkan judul penelitian,maka diketahui variabel yang akan dikaji dalam penelitian ini terdapat dua variabel, yaitu tata tertib sekolah sebagai variabel independen/variabel bebas (X) dan
Prestasi belajar PKn sebagai variabel dependen variabel terikat(Y).

Tertib mencakup setiap macam hubungan yang ditujukan untuk membantu siswa agar dia dapat memahami dan menyesuaikan diri dengan tuntutan lingkungannya dan juga tentang cara menyelesaikan tuntutan yang mungkin ingin ditujukan terhadap lingkungannya (Oemar Hamalik.1988: dalam kegiatan belajar mengajar secara etimologis ungkapan tertib adalah kepatuhan sehingga memerlukan latihan hati dan watak dengan maksud supaya segala perbuatannya sesuai aturan yang ada .jadi aturan dalam proses belajar mengajar adalah suatu kesepakatan bersama menurut lembaga wajib dilaksanakan ,kaarena mempunyai hubungan yang besar terhadap kelancaran proses belajar mengajar.

Jadi tertib belajar siswa suatu perbuatan dan kegiatan belajar yang dilaksanakan sesuai dengan aturan yang telah ditentukan sebelumnya.ketertiban belajar sebagai suatu keharusan yang harus ditaati oleh setia person dalam suatu organisasi dengan sendirinya memiliki aktivitas yang bernilai tambah.unsur pokok dalam tertib belajar siswa adalah tertib kearah siasat.pembahasan dengan tertib disekolah akan mempunyai hubungan yang positif bagi kehidupan siswa dimasa yang akan datang .pada mulanya memang tertib dirasakan sebagai suatu aturan yang menekan kebebasan siswa,tetapi bila aturan ini dirasakan sebagai sesuatu yang memang seharusnya dipatuhi secara sadar untuk kebaikan diri sendiri dan kebaikan bersama ,maka lama kelamaan akan menjadi kebiasaan yang baik menuju kearah terib diri sendiri

\section{Desain Penelitian}

Penelitian ini termasuk penelitian korelasi, yang menunjukkan hubungan ,yaitu hubungan yang bersifat sebab akibat, dimana hal ini dilakukan untuk mengetahui adanya pengaruh variabel independen dengan variabel dependen. 
Untuk lebih jelasnya desain penelitian digambarkan dalam bentuk bagan sebagai berikut:

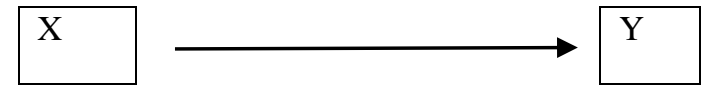

Gambar 2 : Desain kerangka acuan

Dimana:

$\mathrm{X}$ :Kedisiplinan tata tertib dalam belajar disekolah:indikatornya: disiplin dalam proses belajar, (2)disiplin mengerjakan tugas,dan (3)disiplin mengumpulkan tugas.

Y :Prestasi belajar PKn:yaitu nilai yang didapat dalam mata pelajaran PKn pada Semester Ganjil,yaitu nilai RAPOR

\section{Defenisi Operasional dan Pegukuran Varibel \\ Definisi operasional dan} pegukuran variabel deskriptif kuantitatif tentang konrtibusi tata tertib yang akan dikaji dalam penelitan ini perlu dimasukan degan tegas untuk memudahkan dalam pengumpulan data dan pengukurannya sehingga tidak megundang interpretasi yang ganda.

1. Kotribusi adalah sumbangan yang berusmber dari tata tertib untuk meningkatkan prestasi belajar PKN siswa pada SMP Negeri 1 Bajeng.

2. Tata tertib sekolah adalah peraturan-peraturan yang ada di sekolah yang harus dipatuhi dan dilaksanakan oleh peserta didik sebagai wujud kehidupan yang sadar akan hukum atau aturan, yaitu tertib dalam belajar.

3. Prestasi belajar adalah hasil belajar siswa, yaitu nilai rapor yang diambil di semester ganjil tahun ajaran 2015-2016.

"Apabila populasi objek kurang dari 100,lebih baik diambil semua,dan jika populasinya besar maka dapat diambil 10$15 \%$ atau $20-25 \%$ atau lebih tergantung dari kemampuan peneliti". Berdasarkan pertimbangan diketahui bahwa besarnya sampel penelitian ini adalah $150 \mathrm{X}$ $20 \%=30$.

\section{Teknik dan Prosedur Pengumpulan Data}

Untuk kepentingan data guna megetahui masalah yang akan diteliti, maka yang dilakukan pada tempat penelitan sebgai berikut;

1. Angket, teknik angket dimaksud untuk memperoleh data mengenai kedisiplinan tata tertib siswa,dimana angket berisikan pertanyaan-pertanyaan yang mengungkap tentang kedisiplinan siswa dalam meningkatkan prestasi belajar di SMP Negeri 1 Bajeng yang disebarkan kepada responden terrpilih sebanyak 30 peserta didik.

2. Wawancara, adalah mengadakan pembicaraan secara langsung dengan pihak yang berkompeten yakni guru mata pelajaran PKn dan Guru Bimbingan Konseling (BK) dengan penelitian untuk mendapatkan respon/informasi mengenai hal yang akan diteliti dalam hal ini.

3. Dokumentasi ,adalah mengumpulkan data berupa dokumen yang berhubungan dengan penelitian yang akan dilakukan dimana metode pengumpulan data ini berdasarkan pada dokumen-dokumen berupa data-data sekunder yang diperoleh dari SMP Negeri 1 Bajeng.

\section{F. Teknik Analisis Data}

Berdasarkan data yang terkumpul,maka data tersebut dianalisis dengan statistic, model analisis yang digunakan sesuai dengan rancangan penelitiannya yaitu Analisis Pearson Product Moment sebagai berikut:

$\mathrm{r}_{\mathrm{x} \gamma}=\frac{\times \boldsymbol{y}-\frac{\left(\sum x\right)\left(\sum y\right)}{N}}{\sqrt{\left\{\sum x^{2}-\frac{(\Sigma x)^{2}}{N}\right\}\left\{\Sigma y^{2}-\frac{\left(\sum y\right)^{2}}{N}\right\}}}$ 
Keterangan:

$\mathrm{x}=$ Rata-Rata Jumlah skor Kepatuhan Terhadap Tata Tertib

$\mathrm{y}=$ Rata-Rata Jumlah Prestasi belajar yang dicapai

$\mathrm{N}=$ Jumlah sampel

$\mathrm{rxy}=$ product momen

\section{PEMBAHASAN}

1. Bagaimana Kontribusi tata tertib terhadap prestasi belajar PKn di SMP Negeri 1 Bajeng Kabupaten Gowa

Berdasarkan data tabel 4 diperoleh nilai hitung 0,998 yang lebih besar dari nilai tabel sebesar 0,361 pada taraf signifikan $5 \%$ dan $\mathrm{N}=30$. Ini berarti hipotesis penelitian yang berbunyi "Ada Kontribusi Tata Tertib Sekolah Terhadap Prestasi Belajar PKn Siswa Pada SMP Negeri 1 Bajeng,Kabupaten gowa Diterima

Untuk mengetahui apakah Korelasi hasil perhitungan tersebut signifikan atau tidak, maka perlu diadakan pengujian Koefisien Korelasi dengan ketentuan apabila nilai $r$ hitung $>r$ tabel pada taraf signifikan $\alpha=5 \%$ ini berarti ada hubungan yang signifikan begitu pula sebaliknya. Dengan demikian sekarang dibandingkan antara nilai hitung sebesar 0,998 dengan nilai tabel dengan sampel 30 orang pada taraf signifikan $\alpha=5 \%$ sebesar 0,361 maka dapat disimpulkan nilai hitung > nilai tabel pada sampel 30 orang,atau 0,998 >0,361. Hal ini berarti hipotesis diterima yang berbunyi ada kontribusi pelaksanaan tata tertib sekolah dengan prestasi belajar PKn siswa pada SMP Negeri 1 Bajeng telah diterima.

Diterimanya hipotesis penelitian ini berarti ada beberapa hal yang dapat dinyatakan, antara lain: Siswa senantiasa mentaati aturan sekolah dengan prinsip akan membentuk pada pribadi siswa yang berwatak baik yang dapat diwujudkan dalam bentuk tingka laku. Karena sifat seseorang dapat dikategorikan berubah sikap,jika mampu mentaati aturan yang mengikat. Siswa yang teratur cara belajarnya semakin membuka peluang untuk lebih banyak menguasai materi pelajarannya.

Dengan demikian sikap tertib siswa merupakan perwujudan penerapan tata tertib sekolah sebagai kesepakatan antara seluruh personil sekolah, yang senantiasa diterapkan baik dalam kelas maupun diluar kelas. Kondisi ini telah terwujud berkat kesadaran atas hak dan kewajiban setiap personil sekolah (guru dan siswa)

Sikap siswa terhadap tata tertib sekolah, mutlak diperlukan dalam proses pendidikan, karena sikap tata tertib siswa menghubungkan secara positif terhadap kemajuan belajar. Indikator penting tata tertib pembelajaran yang positif adalah antara lain: Tertib dalam Proses Pembelajaran, Tertib mengerjakan tugastugas yang diberikan oleh Guru, dan Tertib Mengumpulkan Tugas. Sikap tertib yang tinggi dapat memperlancar proses kegiatan belajar mengajar siswa SMP Negeri 1 Bajeng Kabupaten Gowa, karena hasil penelitian menunjukkan kadar tertib yang kategori tinggi. Solusi yang terbaik bagi siswa adalah perlu diterapkan sedini mungkin sikap-sikap belajar yang positif, terutama membiasakan diri belajar dengan teratur. Kondisi ideal pada diri siswa sesungguhnya menyadari bahwa tata tertib yang baik akan menghubungkan secara positif terhadap prestasi belajar siswa ,namun harus diakui bahwa sebagian siswa kurang tertib dalam pengaturan waktu belajarnya, oleh sebab itu salah satu masalah pokok yang dihadapi oleh sebagian siswa adalah kesukaran dalam mengatur waktu belajar secara tepat, sehingga kesadaran akan keterbukaan siswa terhadap masalah yang dihadapi sangat diperlukan oleh guru. Hal ini dimaksudkan proses bimbingan belajar yang tepat dan kontinyu

Tujuan akhir dari pendidikan tertib adalah terbentuknya tertib diri sendiri. Apabila seorang anak telah dapat bereaksi secara baik terhadap pengarahan orang 
dewasa maka sebenarnya anak itu telah melalui dengan sukses suatu babakan dari kematangan sosial dan emosional. Apabila proses ini bertumbuh terus dimana anak itu semakin menjadi remaja yang bertanggung jawab dan matang berfikir,maka ia akan mulai berfikir bagaimana ia menyumbang dan mengembangkan serta bertanggung jawab terhadap kelompoknya dan akhirnya terhadap masyarakat dan lingkungannya

\section{Kendala-kendala yang dihadapi pihak Sekolah dalam penegakan Tata tertib di SMP Negeri 1 Bajeng}

Dari data hasil wawancara guru PKn dan guru Bimbingan Konseling (BK) diperoleh data mengenai kendala-kendala penegakan tata tertib Di SMP Negeri 1 Bajeng sebagai berikut:

a. Kerja sama antara guru BK dengan guru mata pelajaran, dan wali kelas belum maksimal.

Penyelengaraan bimbingan dan konseling disekolah bukan hanya menjadi tanggung jawab guru bimbingan dan konseling (BK) melainkan menjadi tanggung jawab bersama semua guru, baik wali kelas maupun guru mata pelajaran dibawah koordinasi guru bimbingan dan konseling, sekalipun tugas dan tanggung jawab utama guru kelas maupun guru mata pelajaran adalah menyelenggarakan kegiatan belajar dan pembelajaran, bukan berarti dia sama sekali lepas dari kegiatan pelayanan bimbingan dan konselingPeran dan Kontribusi semua guru sangat diharapkan guna kepentingan efektifitas dan efesiensi proses belajar mengajar disekolah

b. Orang tua siswa belum terlalu peduli kepada Anaknya

Kenakalan siswa yang sering terjadi dipengaruhi oleh kurangnya pengawasan dari orang tua.orang tua terlalu sibuk dengan pekerjaan sehingga dia lupa akan hak dan kewajiban sebagai orang tua untuk mendidik anaknya
Sesungguhnya sesibuk apapun orang tua tanggung jawab mereka terhadap anak tidak perna bisa tergantikan oleh siapapun. Selama hayat masih dikandung badan selama itu juga kewajiban mereka masih tetap ada, apalagi kita tahu bahwa tidak ada yang namanya mantang guru, sebagaimana tidak ada mantang murid. Sementara orang tua mempunyai dua profesi utama yaitu sebagai orang tua dan guru bagi anaknya.

Harapan terbesar orang tua adalah ingin memiliki anak yang soleh,pandai bergaul,pintar dan sukses tetapi harapan besar ini jangan sampai menjadi tinggal harapan saja. Bagaimana orang tua mewujudkan harapan tersebut itulah yang paling penting kedudukan dan fungsi suatu keluarga dalam kehidupan sangatlah penting dan fundamental. Keluarga merupakan wadah pembentukan masingmasing anggotanya terutama anak yang masih berada dalam bimbingan tanggung jawab orang tua.

\section{Upaya -upaya yang dilakukan dalam penegakan tata tertib di sekolah SMP Negeri 1 Bajeng}

a. Memberikan pengarahan kepada siswa Guru merupakan seseorang yang bertugas menyelenggarakan kegiatan belajar mengajar, bimbingan, melatih, mengelola dan mengembangkan serta memberikan pelayanan teknik, guru memiliki tugas pokok melaksanakan proses belajar mengajar karna itu setiap guru harus memiliki kebijakan-kebijakan atau wewenang yang professional dan kepribadian yang baik.

Peserta didik merupakan orang yang diberi masukan dalam proses pendidikan sebagai organisme yang hidup, memiliki potensi untuk berkembang yang memerlukan lingkungan dan arah tertentu sehingga membutuhkan suatu bimbingan dalam belajar.

b. Menjalin Kerja sama dengan orang tua siswa demi pendidikan dan 
pengembangan diri anak buat masa depannya harus ada sinergi positif antara orang tua siswa dengan guru disekolah. Sehingga peserta didik senantiasa tetap berada dalam kontrolkontrol. Dengan demikian peserta didik tidak mempunyai peluang untuk melakukan hal-hal yang mengarah pada tindakan yang melanggar.

Hubungan kerja sama antara guru dan orang tua peserta didik sangatlah penting untuk meningkatkan mutu pendidikan dan menjadikan peserta didik mempunyai tanggung jawab dalam pengambilan keputusan.

c. Pemberian Contoh Keteladanan

Setiap kegiatan pasti mempunyai tujuan yang akan dicapai sebagai seorang pendidik menanamkan prinsip-prinsip yang lurus dan pengarahan yang benar kedalam jiwa dan perilaku pesrta didik. Kesempatan itu terbuka lebar segala sarana dan prasarana juga mendukung mengingat anak dalam pengawasan orang tua dirumahnya dalam berprilaku yang baik.

\section{PENUTUP}

\section{Kesimpulan}

Berdasarkan pembahasan pada bab sebelumnya maka dapat disimpulkan sebagai berikut:

1. Ada Kontribusi Tata Tertib Sekolah dengan Peningkatan Prestasi Belajar PKn Siswa Pada SMP Negeri 1 Bajeng kabupaten gowa. Dilihat dari uji korelasi product moment menunjukkan nilai koefisien korelasi 0,998 kemudian dikonsultasikan pada taraf signifikan $\breve{\alpha}=5 \%$ sebesar 0,361 yang artinya nilai hitung > nilai tabel.

2. Kendala-kendala yang dihadapi pihak sekolah dalam penegakan tata tertib di SMP Negeri 1 Bajeng kabupaten gowa adalah: kerja sama antar guru BK dengan guru mata pelajaran dan wali kelas belum maksimal, orang tua siswa belum terlalu peduli kepada anaknya.

3. Upaya-upaya yang dilakukan pihak sekolah dalam hal penegakan tata tertib di SMP Negeri 1 Bajeng kabupaten gowa,adalah : Memberikan pengarahan kepada peserta didik, menjalin kerja sama dengan orang tua siswa, dan pemberian contoh keteladanan.

\section{DAFTAR PUSTAKA}

Ali Mohamad. 1985. Penelitian Kependidikan Prosedur dan Strategi. Pustaka Bandung

Abin Syamsuddin Makmun. 1981. Psikologi Pendidikan. Pustaka Nartiana. Bandung.

Achamd Bahar. 1989. Penuniun Praktis Cara Belajar dan mengajar yang Efisisen. Karya, Bandung.

Arikunto Suharsimi. 1991. Prosedur Penelitian, Suatu Pendekatan Praktik, Rineke Cipta, Jakarta.

Conny Semiwawan. 1989. Pendekatan Keterampilan Proses. PT. Gramedia. Jakarta.

Edi Suardi. 1980. Teknik Belajar yang efektif. Balai Pustaka. Jakarta.

Muhibbinsyah. $1995 . \quad$ Psikologi Pendidikan. PT Remaja Rosdakarya Bandung.

Nurul Zuriah Pendidikan moral dan budi pekerti dalam perseptif perubahan, PT Bumi Aksara. Jakarta 2008

Ali Imron, Manajemen peserta didik berbasis sekolah, PT Bumi Aksara, Jakarta 2012

Education For Character "Bagaimana Sekolah Dapat Mengajarkan Sikap Hormat Dan Tanggung Jawab" Penerbit Pt Bumi Aksara 2013

Elsantoso. (Tanpa Tahun). Kamus Populer Indonesia. Balai Pustaka Jakarta. 
Hasibuan J. 1988. Proses Belajar Mengajar Keterampilan Dasar .Remaja Karya Bandung.

Harun Utuh.1986.Proses Belajar Mengajar PMP. Usaha Nasional Surabaya
Simanjuntak J.P. 2001 teori Belajar ,Motivasi dan keterampilan mengajar Depdikbud: Jakarta .

Suryabrata , Sumadi. 2011. Psikologi pendidikan . Jakarta : PT Raja Grafindo Persada.

Hadi,Sutrisno .1981. Metodologi Research 2. UGM: Yogyakarta 